\title{
ПОРУШЕННЯ ТРАДИЦЙННӦ̈ СПОЛУЧУВАНОСТІ ЯК МЕХАНІЗМ ВИНИКНЕННЯ ВАРІАТИВНОСТІ РОЗУМІННЯ (НА ПРИКЛАДІ ТЕКСТІВ БІЛОРУСЬКИХ ІНТЕРНЕТ-НОВИН)
}

Акімова Н. В. Порушення традиційної сполучуваності як механізм виникнення варіативності розуміння (на прикладі текстів білоруських інтернет-новин).

У статті розглянуто, як порушення традиційної сполучуваності мовних одиниць, зумовлене специфікою мови інтернету, ускладнює розуміння текстів білоруських інтернет-новин.

Ключові слова: варіативність, розуміння, порушення сполучуваності, сайти новин, мова інтернету, психолінгвістика.

Акимова Н. В. Нарушение традиционной сочетаемости как механизм возникновения вариативности понимания (на примере текстов белорусских интернет-новостей).

В статье рассматривается, как нарушение традиционной сочетаемости языковых единиц, обусловленное спецификой языка интернета, усложняет понимание текстов белорусских интернет-новостей.

Ключевые слова: вариативнисть, понимание, нарушение сочетаемости, сайты новостей, язык интернета, психолингвистика.

Akimova N. V. Violation of traditional compatibility as a mechanism of appear of the understanding variability (on the example of the Byelorussian internetnews texts).

In the article it is considered, how violation of traditional compatibility of linguistic units, predefined by the specifics of internet language, complicates understanding of the Byelorussian internet news texts.

Key words: variability, understanding, violation of compatibility, news sites, internet language, psycholinguistics.

Однією 3 тенденцій сучасної лінгвістичної науки є розширення об'єкта дослідження. 3 одного боку, останні дослідження все частіше спираються на методологію немовознавчих наук (психології, культурології тощо), 3 іншого, - прагнуть розширити предмет вивчення, тому, наприклад, аналіз дискурсу, концептуальної структури або мови інтернету сьогодні вже є лінгвістичною тематикою.

У руслі тенденцій сучасної науки визначимо мету цієї розвідки як аналіз того, як порушення традиційної сполучуваності тексту сприяє виникненню варіативності розуміння білоруських інтернет-новин.

Текст інтернету описується такими ознаками, як гібридність, креолізованість (або мультимедійність), використання «смайликів» i специфічних скорочень, високий ступінь проникності, колективне 
співавторство і співредактура тексту, насиченість неологізмами, недотримання мовних норм, необмеженість у виборі мовних засобів, схильність до мовної гри, фрагментарність, функціонування особливого мовленнєвого етикету, виражений презентативний характер (M. Boardman, S. Daya, E. Dresner, S. Herring, J. Masson, C. Werry, Н. Г. Асмус, В. Бойка, О. М. Галічкіна, О. І. Горошко, О. В. Дєдова, І. Ю. Сгорова, І. Б. Карпа, М. О. Ковальчукова, Т. М. Колокольцева, Л. Ф. Компанцева, С. О. Лисенко, С. А. Матвєєва, Н. Л. Моргун, О. М. Саєнко, П. І. Сергієнко, П. В. Шкапенко, Л. Ю. Щипіцина та ін.) [1-5; 7-9; 11-23; 26; 27].

Розглянемо, як втілюються специфічні риси мови інтернету в конкретних прикладах 3 текстів найбільш відвідуваних білоруських сайтів новин та як це впливає на процес розуміння.

Гібридність мови інтернету виражається у змішування лексики різних стилів, наприклад: Экс-міністр эканомікі Расеі: Лукашэнка не партнер, а халявшиык [25 від 9.11.2012]. Грубе розмовне «халявичык» (від «халява» у другому значенні - «1) хітруючы, нічога не робячы (жыць, пражыць i пад.); на дурніцу. Пражыць жыццё на халяву; 2) бясплатна, дарэмна, нічога не плацячы (рабіць што-н., выпіваць)» [24]) погано поєднується 3 іншим текстом. Багатозначність слова «халява» провокує варіанти інтерпретації анонсу.

Прикладом виникнення варіативності через порушення сполучуванності картинки та тексту може бути ілюстрований новинний анонс: Против белорусских властей восстали деревья [6 від 4.11.12]. Звучний вираз «восстали против властей» аж ніяк не передбачає як суб’єкта дерева, та й малюнок із зображенням кількох дерев не містить опор для декодування тексту.

Колективні співавторство і співредактура здебільшого помітні якраз тоді, коли між частинами одного невеликого тексту (новинного анонсу) слабкий семантичний зв' язок: Лукашэнка ў Кіеве затыкаў рты $i$ край кампутары (Фота). У сталіцьь Украіны прайшоў перфоманс у падтрымку свабоды слова ў Беларусі [25 від 20.07.2012]. Такі фрагменти в першу чергу свідчать про низький рівень кваліфікації їх авторів, а потім вже підштовхують шукати якийсь потаємний код, що об'єднує подібні речення в цілісний текст.

Про недотримання мовних норм свідчать численні приклади порушення різних правил, зокрема й стилістичних. Так, в одному анонсі йдеться: Эксперт: Власти нанесли Беларуси ущеерб в миллиарды долларов [6 від 4.11.12]. Контамінація синтаксично зв'язаних виразів «нанести вред» та «причинить ущерб» провокує варіанти тлумачення анонсу.

Використання цитат епатажних діячів сучасності нерідко веде до появи в мові інтернету грубої, а іноді й відверто інвективної лексики, наприклад: Сергей Михалок: Мы из той страны, где былло и сволочи 
правят спокойным, красивым и очень умным народом [6 від 7.10.12]. Окрім стилістичної неузгодженості акцентованих лексем із контекстом, в аналізованому анонсі постає питання інтерпретаційної неузгодженості: незрозуміло, ці слова називають двох різних суб'єктів чи $\epsilon$ характеристиками одного суб'єкта?

Переосмислення i трансформації різних прецедентних виразів демонструють схильність до мовної гри в текстах Мережі, хоч іноді таку мовну гру важко назвати вдалою, наприклад: Neuro Dubel: Hac запретила вся белорусская система, просвета в "черных списках» нет [6 від 28.11.12]. Уживання слова «просвет» («промежуток, свободное пространство между какими-л. близко расположенными предметами» [10, с. 1023]) у переносному значенні разом із метафорою «черный список» стирає ефект мовної гри «світло-темрява» через нераціональні зусилля декодувати зазначені елементи. Насиченість анонсу девіантними мовленнєвими одиницями не дає змоги зрозуміти, кого заборонили, чому, як тощо.

Фрагментарність інтернет-текстів простежується в механічному поєднанні в певному анонсі зовсім різної інформації, об'єднаної лише імпліцитним задумом автора: Суд назначил виновным... компьютер [25 від 20.07.12]. Оригінальність поєднання виразу «назначил виновнылм» зі словом «компьютер» зумовлює варіативність тлумачення цього тексту.

Особливий мовленнєвий етикет інтернету виникає у зв'язку зі специфічним використанням загальновживаної лексики. У прагненні до максимальної яскравої презентативності й емоційності автори часто нехтують елементарними законами сполучуваності, як наслідок маємо Хитро работаем. Небывалая валютная выручка обрушилась на Беларусь [25 від 20.07.2012]. Лексема «выручка» у другому значенні «деньги, прибыль, полученные от продажи чего-л.» [10, с. 181] (це значення підтримується контекстом, зокрема прикметником «валютная») не узгоджується зі словом «обрушиться», яке трактується як «1. Разрушаясь, обвалиться, рухнуть. 2. С силой низвергнуться на кого-, что-л. (о дожде, волнах и т.п.). 3. на кого-что. Стремительно, с большой силой напасть на кого-, что-л., атаковать кого-, что-Л.» $[10$, с. 685]. Реципієнт має додумати відсутній зв'язок. Варіанти домислювання і будуть варіантами розуміння білоруського анонсу. Надмірна емоційність використовуваних мовних одиниць значно ускладнює коректну інтерпретацію тексту, а іноді робить їі неможливою.

Отже, варіативність інтерпретації текстів білоруських інтернетновин зумовлена порушенням традиційної сполучуваності мовних одиниць у тексті, що пов'язана 3 гібридністю та мультимедійністю, колективним співавторством і співредактурою, недотриманням мовних норм, необмеженістю у виборі мовних засобів, схильністю до мовної гри, фрагментарністю, функціонуванням особливого мовленнсвого етикету та ○ Н. В. Акімова, 2013. 
яскраво вираженим презентативним характером мови інтернету.

У перспективі плануємо дослідити особливості розуміння подібних новинних анонсів за допомогою асоціативного та рецептивного експериментів.

\section{Література}

1. Boardman M. The Language of Websites / M. Boardman. - New York: Routledge, 2004. -102 p.

2. Dresner E. The Topology of Auditory and Visual Perception, Linguistic Communication, and Interactive Written Discourse [Електроний ресурс] / E. Dresner // Language@Internet. $\quad$ - $2005 . \quad$ 2 200 Режим доступу : http://www.languageatinternet.de/articles/2005

3. Herring S. Language and the Internet /Herring S. // International Encyclopaedia of Communication. - Blackwell: Blackwell Publishers, 2008.

4. Mason J. From Gutenberg's Galaxy to Cyberspace: The Transforming Power of Electronic Hypertext, doctoral dissertation at McGill University, Montral [Электронный pecypc] / J. Mason. - Режим доступа : http://www.masondissertation.elephanthost.com

5. Sin Daya Thematic and Situational Features of Chinese BBS Texts [Електроний pecypc] / Sin Daya // Language@Internet. - 2009. - Vol. 6. - Режим доступу: http://www.languageatinternet.de/articles/2009/2011

6. UDF.BY - Новости Беларуси [Електронний ресурс] - Режим доступу : http://udf.by/

7. Werry C. Linguistic and Interactional Features of Internet Relay Chat // ComputerMediated Communication: Linguistic, Social and Cultural Perspectives / S. Herring. Amsterdam: Benjamins, 1996. - P. 47-64.

8. Асмус Н. Г. Лингвистические особенности виртуального коммуникативного пространства : дис. на соискание уч. степени кандидата филологических наук : спец. 10. 02.19 - «Теория языка» / Н.Г.Асмус - Челябинск, 2005 - 265 с.

9. Бойка В. Слэнгавая лексіка ў беларускамоўным інтэрнэт-дыскурсе / В. Бойка // Актуальныя праблемы мовазнаўства і лігвадыдактыкі : матэрыялы Рэспубліканскай навуковай канферэнцы (да 70-годдзя з дня нараджэння прафесара Галіны Мікалаеўны Малажай), Брэст, 20-21 сакавіка 2008 г. / пад агул. рэд. М. І. Новік; [рэдкал. : М. І.Новік, В. М. Касцючык, Л. І. Яўдошына, С. Ф. Бут-Гусаім]. - Брэст : БрДУ, 2008. - С. 265-267.

10. Большой толковый словарь русского языка / Гл. ред. С. А. Кузнецов. - СПб. : Норинт, 2009. - 1536 с.

11. Галичкина Е. Н. Специфика компьютерного дискурса на английском и русском языках (на материале жанра компьютерных конференций) : дис. ... канд. филол. наук : 10.02 .20 «Прикладная и математическая лингвистика» / Е. Н. Галичкина. - Волгоград, 2001. - 212 с.

12.Горошко Е. И. Текст эпохи веб 2.0 : психолингвистический анализ [Электронный ресурс] / Е. И. Горошко. - Режим доступа : http://www.textology.ru

13. Дедова О. В. Лингвосемиотический анализ электронного гипертекста : (на материале русскоязычного Интернета) : дис. ... д-ра филол. наук : 10.02.01 «Русский язык» [Электронный ресурс] / О. В. Дедова. - Режим доступа : http://www.dissercat.com

14. Егорова И. Ю. Акцентирование в рекламном интернет-дискурсе : автореф. дис.. ... канд. филол. наук : 10.02.19 «Теория языка» / И. Ю. Егорова. - Волгоград, 2008. - 31 с.

15. Карпа І. Б. Функціональні та прагматичні характеристики інтерактивної віртуальної комунікації (на матеріалі інформаційно-довідкового сервісу Yahoo!Answers) : автореф. дис. ... канд. філол. наук : 10.02.04 «Германські мови» / І. Б. Карпа. - Херсон, 2010. - 22 с.

16. Ковальчукова М. А. Новостной анонс в сети интернет как речевой жанр дискурса СМИ : автореф. дис. ... канд. филол. наук : 10.02.19 «Теория языка» / М. А. Ковальчукова. - Ижевск, 2009. - 26 с. 
17. Колокольцева Т.Н. Интернет-коммуникация как зеркало основных тенденций развития и функционирования русского языка [Электронный ресурс] / Т. Н. Колокольцева // Электронный научно-образовательный журнал ВГПУ «Грани познания». - 2011. - №4 (14). - Режим доступа : www.grani.vspu.ru

18. Компанцева Л. Ф. Інтернет-комунікація: когнітивно-прагматичний та лінгвокультурологічний аспекти : автореф. дис. ... д-ра філол. наук : 10.02 .02 «Російська мова» / Л. Ф. Компанцева. - К., 2007. - 23 с.

19. Лысенко С. А. Взаимодействие устной и письменной формы существования языка в интернет-коммуникации : дис. ... канд. филол. наук : 10.02.19 «Теория языка» / С. А. Лысенко. - Воронеж, 2010 - 184 с.

20. Матвєєва С. А. Сайт як жанр Інтернет-комунікації (на матеріалі персональних сайтів учених) : автореф. дис. ... канд. філол. наук : 10.02.15 «Загальне мовознавство» / С. А. Матвєєва. - Донецьк, 2006. - 21 с.

21. Моргун Н. Л. Научный сетевой дискурс как тип текста : автореф. дис. ... канд. филол. Наук : спец. 10.02.01 «Русский язык» / Н. Л. Моргун. - Тюмень, 2002. - 20 с.

22. Саенко А. Н. Содержательно-стилистические особенности информационных текстов в Интернете / А. Н. Саенко // Научные записки Луганского национального педагогического университета. Вып. 5. Т. 1. Серия «Филологические науки» : сб. научн. тр. - Луганськ : «Альма-матер», 2004. - С. 350-360.

23. Сергиенко П. И. Лингвокогнитивные особенности электронного гипертекста (на материале английского языка) : автореф. дис. ... канд. филол. наук : 10.02 .04 «Германские языки» / П. И. Сергиенко. - М., 2009. - 22 с.

24. Халявшчык / Родныя Вобразы / Тлумачальны слоўнік [Електронний ресурс] Режим доступу : http://www.rv-blr.com/slounik

25. Хартыя'97 - Навіны з Беларусі - Беларускія навіны - Рэспубліка Беларусь Мінск [Електронний ресурс]. - Режим доступу : http://www.charter97.org/

26. Шкапенко П. В. Специфика реализации прагмалингвистических принципов в интернет-дискурсе : автореф. дис. ... канд. филол. наук : 10.02 .04 - «Германские языки» / П. В. Шкапенко. - М., 2008. - 29 с.

27. Щипицина Л. Ю. Комплексная лингвистическая характеристика компьютерноопосредованной коммуникации (на материале немецкого языка) : автореф. дис. ... д-ра филол. наук : 10.02.04 «Германские языки» / Л. Ю. Щипицина. - Воронеж, 2011. - 40 с. 